\title{
Phase I study of a new radiosensitizer containing hydrogen peroxide and sodium hyaluronate for topical tumor injection: A new enzyme-targeting radiosensitization treatment, Kochi Oxydol-Radiation Therapy for Unresectable Carcinomas, Type II (KORTUC II)
}

\author{
YASUHIRO OGAWA ${ }^{1}$, KEI KUBOTA ${ }^{1}$, HIRONOBU UE ${ }^{1}$, YUKO KATAOKA ${ }^{1}$, MICHIKO TADOKORO ${ }^{1}$, \\ KANA MIYATAKE ${ }^{1}$, KAZUHIRO TSUZUKI ${ }^{1}$, TOMOAKI YAMANISHI ${ }^{1}$, SATOSHI ITOH ${ }^{1}$, \\ JIRO HITOMI ${ }^{1}$, NORIHIKO HAMADA ${ }^{1}$, SHINJI KARIYA ${ }^{1}$, MITSUTAKA FUKUMOTO ${ }^{1}$, \\ AKIHITO NISHIOKA $^{1}$ and TAISUKE INOMATA ${ }^{2}$ \\ ${ }^{1}$ Department of Diagnostic Radiology and Radiation Oncology, Medical School, Kochi University, Kochi 783-8505; \\ ${ }^{2}$ Department of Radiology, Osaka Medical College, Osaka 569-8686, Japan
}

Received October 23, 2008; Accepted November 27, 2008

DOI: 10.3892/ijo_00000186

\begin{abstract}
Using a currently employed linear accelerator, our intent was to inactivate peroxidase/catalase in tumor tissue by the application of hydrogen peroxide, which is degraded to produce oxygen, thus re-oxygenizing the tumor tissue. In this way, we can convert radioresistant tumors into radiosensitive ones. On the basis of this strategy, we previously developed a new enzyme-targeting radiosensitization treatment named KORTUC I, which remarkably enhances the radiotherapeutic effect on various types of superficially exposed and locally advanced malignant neoplasms. Based on our clinical experience using KORTUC I, we also developed a new radiosensitizer containing hydrogen peroxide and sodium hyaluronate for injection into various types of tumors that are not superficially exposed (KORTUC II; described herein). KORTUC II was approved by our local ethics committee for advanced skin cancer, including malignant melanoma, bone/soft tissue malignant neoplasms, breast cancer, and metastatic lymph nodes. A maximum of $6 \mathrm{ml}$ of the agent was injected into tumor tissue one to two times per week under ultrasonographic guidance, just prior to each administration of radiation therapy. Eleven patients, including seven with breast cancer, were enrolled in the
\end{abstract}

Correspondence to: Dr Yasuhiro Ogawa, Department of Diagnostic Radiology and Radiation Oncology, Medical School, Kochi University, Oko-cho, Nankoku-shi, Kochi 783-8505, Japan E-mail: ogaway@kochi-u.ac.jp

Key words: radiosensitizer, hydrogen peroxide, sodium hyaluronate, breast cancer, breast-conservation treatment, intratumoral injection
KORTUC II trial upon fully informed consent. KORTUC II was well tolerated, with a minimum of adverse effects. Nine of the 11 patients showed a complete response (CR), and no severe complications occurred in any of the 11 patients. This new enzyme-targeting radiosensitization treatment may be indicated for various types of locally advanced neoplasms, including soft tissue neoplasms and breast cancers.

\section{Introduction}

During radiotherapy delivered by a linear accelerator (Linac) in current use, our intent was to inactivate peroxidase/catalase in tumor tissue by the application of hydrogen peroxide, thus re-oxygenizing the tumor tissue with the oxygen produced by the degradation of hydrogen peroxide. We have previously shown that a low dose of hydrogen peroxide can cause radiation-induced apoptosis in a radioresistant osteosarcoma cell line, HS-Os-1, demonstrating that hydrogen peroxide has strong activity as a new radiosensitizer (1-3).

In this way, we can convert radioresistant tumors into radiosensitive ones. On the basis of our experimental results, we have developed a new enzyme-targeting radiosensitization treatment, Kochi Oxydol-Radiation Therapy for Unresectable Carcinomas, Type I (KORTUC I). This remarkably enhances the radiotherapeutic effect on various types of superficially exposed and locally advanced malignant tumors including soft tissue neoplasms and breast cancers, as described previously (4). In the KORTUC I method, the surface of the tumor is covered by $3 \%$ hydrogen peroxide solution (Oxydol)-soaked gauze during each administration of radiation therapy. Based on our clinical experiences using KORTUC I, we went on to develop a new radiosensitizer containing hydrogen peroxide and sodium hyaluronate for injection into various types of tumors that are not superficially exposed. The concepts underlying this new enzymetargeting radiosensitization treatment, KORTUC II, are shown 


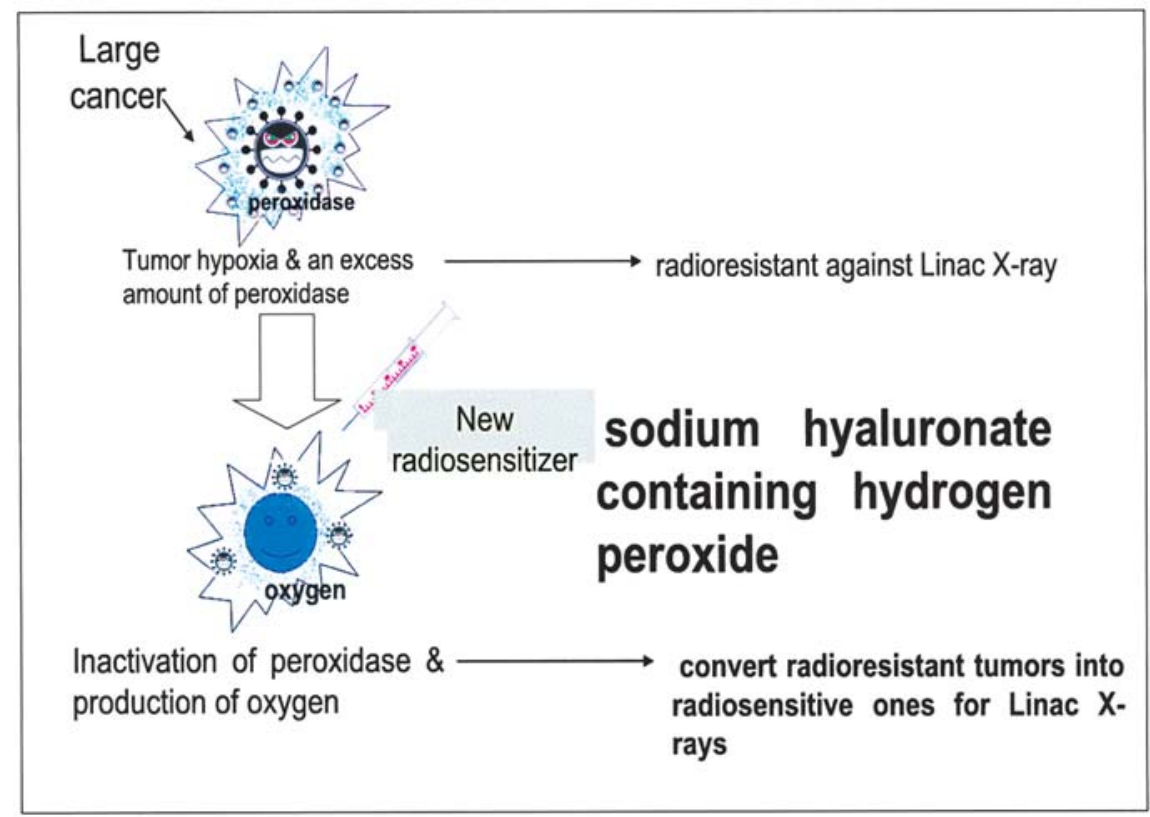

Figure 1. Concepts underlying the new enzyme-targeting radiosensitization treatment.

in Fig. 1. The goal of the present study was to ascertain the feasibility and tolerability of our new approach.

\section{Materials and methods}

In the present study, we describe KORTUC II radiosensitization therapy using a new radiosensitizer containing hydrogen peroxide and sodium hyaluronate. This was used in injection of several types of tumor: locally advanced skin cancer including malignant melanoma, bone/soft tissue tumor, breast cancer, and metastatic lymph nodes, as approved by our local ethics committee. In contrast to our previous method utilizing Oxydol-soaked gauze, the present method requires the injection of hydrogen peroxide directly into the non-superficially exposed tumor. Prior to clinical application, we performed experimental studies to ascertain safety of the method (5). Since hydrogen peroxide is an irritant that may cause severe adverse effects, we developed a new hydrogen peroxide-containing radiosensitizer that is safe for injection, effectively conferring radiosensitivity while avoiding irritation of the local tissue. This was achieved through the addition of sodium hyaluronate, which makes the solution more viscous and slows the degradation of hydrogen peroxide, allowing long-acting radiosensitization of the local tumor tissue (5). Preservation of high oxygen concentration in tumor tissue for $>24 \mathrm{~h}$ was experimentally confirmed by intratumoral injection of the agent (unpublished data).

Preparation of the radiosensitizing agent. The radiosensitizing agent is composed of $0.83 \%$ sodium hyaluronate and $0.5 \%$ hydrogen peroxide. It is currently prepared by adding $0.5 \mathrm{ml}$ of 3\% hydrogen peroxide solution (Oxydol, Ken-ei Pharmaceutical Co. Ltd., Osaka, Japan) into a commercially available disposable syringe containing $2.5 \mathrm{ml}$ of $1.0 \%$ sodium hyaluronate, which is ordinarily used for intra-articular injection in chronic knee joint disorders. Hydrogen peroxide is added just before use in order to avoid the degradation of sodium hyaluronate by the oxidative effect of hydrogen peroxide.

Patient selection and radiotherapy. Eleven patients, including seven with breast cancer, were enrolled in the KORTUC II trial upon fully informed consent, and each patient signed an informed consent form before joining the study. Patient data are summarized in Tables I and II. Patients were eligible for this study if they had locally advanced and/or recurrent malignant neoplasms or contraindications to general anesthesia due to significant comorbidity, or if they had declined surgical treatment.

For these patients, radiation therapy with high-energy Xray was delivered with an EXL-20TP linear accelerator equipped with a multi-leaf collimator (Mitsubishi Electric Co. Ltd., Tokyo, Japan) at an appropriate energy level (4, 6, or $10 \mathrm{MV}$ ) depending on the depth of each lesion. For patients with breast cancer, hypofraction radiotherapy was given using a tangential field approach; energy level was 4 $\mathrm{MV}$, total radiation therapy dose was $44 \mathrm{~Gy}$, administered as $2.75 \mathrm{~Gy} /$ fraction $(6,7)$. For those with cancers other than breast cancer, total dose was $60 \mathrm{~Gy}$, with each fraction size being 2 Gy. Radiation therapy was performed five times a week for each patient. After starting radiotherapy, intratumoral injection of our new radiosensitizer was performed under ultrasonographic guidance twice a week for two weeks, and then once a week thereafter, just prior to radiation therapy. A maximum of $6 \mathrm{ml}$ of the agent was injected.

Patient assessment. Tumor response was assessed according to the RECIST criteria (8), and patient monitoring and tumor assessment were carried out at regular intervals of once a month. Patients were assigned a toxicity grade from a standard assessment scale (NIH common toxicity criteria). Treatmentrelated complications were assessed in detail to evaluate the feasibility of this approach. These patients were followed-up for $>12$ months. 
Table I. Summarized data for the patients treated with KORTUC II.

\begin{tabular}{|c|c|c|c|c|}
\hline Case & Disease & Age/sex & Therapeutic effect & Adverse effects \\
\hline 1 & $\begin{array}{l}\text { Locally advanced breast cancer } \\
\text { (multi-drug resistant) }\end{array}$ & $58 / \mathrm{F}$ & $\begin{array}{l}\text { CR (op. performed after } \\
3 \text { months) }\end{array}$ & Mild dermatitis, grade I \\
\hline 2 & $\begin{array}{l}\text { Malignant fibrous histiocytoma } \\
\text { (recurrent, left thigh) }\end{array}$ & $91 / \mathrm{M}$ & $\begin{array}{l}\text { CR for } 6 \text { months } \\
\text { (injection site) }\end{array}$ & Mild dermatitis, grade I \\
\hline 3 & $\begin{array}{l}\text { Malignant schwannoma } \\
\text { (recurrent, rt. foot) }\end{array}$ & $73 / \mathrm{F}$ & $\begin{array}{l}\text { NC (stable disease) } \\
\text { for } 6 \text { months }\end{array}$ & Mild dermatitis, grade I \\
\hline 4 & $\begin{array}{l}\text { Fibrosarcoma } \\
\text { (recurrent, rt. thigh) }\end{array}$ & $75 / F$ & CR for 5 months & Mild dermatitis, grade I \\
\hline 5 & Breast cancer (T2N0) & $88 / \mathrm{F}$ & $\begin{array}{l}\text { CR for }>15 \text { months. } \\
\text { Now, NED }\end{array}$ & Mild dermatitis, grade I \\
\hline 6 & $\begin{array}{l}\text { Breast cancer }(\mathrm{T} 2 \mathrm{~N} 0)+\text { heart } \\
\text { failure + allergy }\end{array}$ & $78 / \mathrm{F}$ & $\begin{array}{l}\text { CR for }>14 \text { months } \\
\text { Now, } \text { NED }^{\mathrm{a}}\end{array}$ & Mild dermatitis, grade I \\
\hline 7 & $\begin{array}{l}\text { Bilateral breast cancer } \\
\text { (lt.:T2N0, rt.:T1cN0) }\end{array}$ & $79 / \mathrm{F}$ & $\begin{array}{l}\text { Both sides: } \\
\text { CR for }>12 \text { months } \\
\text { Now, } \text { NED }^{\mathrm{a}}\end{array}$ & Mild dermatitis, grade I \\
\hline 8 & $\begin{array}{l}\text { Breast cancer } \\
\text { (T2N0, lt. E region, op. refused) }\end{array}$ & $59 / \mathrm{F}$ & $\begin{array}{l}\text { CR for }>11 \text { months } \\
\text { Now, } \mathrm{NED}^{\mathrm{a}}\end{array}$ & Mild dermatitis, grade I \\
\hline 9 & $\begin{array}{l}\text { Breast cancer } \\
(\mathrm{T} 1 \mathrm{cN} 0)\end{array}$ & $77 / F$ & $\begin{array}{l}\text { CR for } 11 \text { months } \\
\text { Now, NED }\end{array}$ & Mild dermatitis, grade I \\
\hline 10 & Primary lesion of breast cancer (stage IV) & $63 / \mathrm{F}$ & CR for 10 months & Mild dermatitis, grade I \\
\hline 11 & $\begin{array}{l}\text { Huge sized-metastatic lymph nodes of } \\
\text { rt. neck (SCC) }\end{array}$ & $57 / \mathrm{M}$ & Good PR for 5 months & Mild dermatitis, grade I \\
\hline
\end{tabular}

${ }^{\mathrm{a} N E D}$, no evidence of disease.

Table II. Adverse events that occurred in the study

\begin{tabular}{|c|c|c|c|c|c|c|}
\hline Case no. & Adverse event & Duration (day) & Severity & Cause & Action & Outcomes \\
\hline 1 & Local pain & 2 & Mild & Injection & None & Resolved \\
\hline 3 & Local pain & 3 & Mild & Injection & None & Resolved \\
\hline 4 & Local pain & 1 & Mild & Injection & None & Resolved \\
\hline 7 & Local pain & 1 & Mild & Injection & None & Resolved \\
\hline 8 & Local pain & 1 & Mild & Injection & None & Resolved \\
\hline 11 & Local pain & 1 & Mild & Injection & None & Resolved \\
\hline
\end{tabular}

\section{Results}

Patient data are summarized in Table I. Eleven patients, including with breast cancer, were enrolled in the KORTUC II trial upon fully informed consent. Nine patients achieved complete response (CR), one showed partial response (PR), and the other had no change (NC). Six of the patients with $\mathrm{CR}$ had breast cancer and were unable or unwilling to 


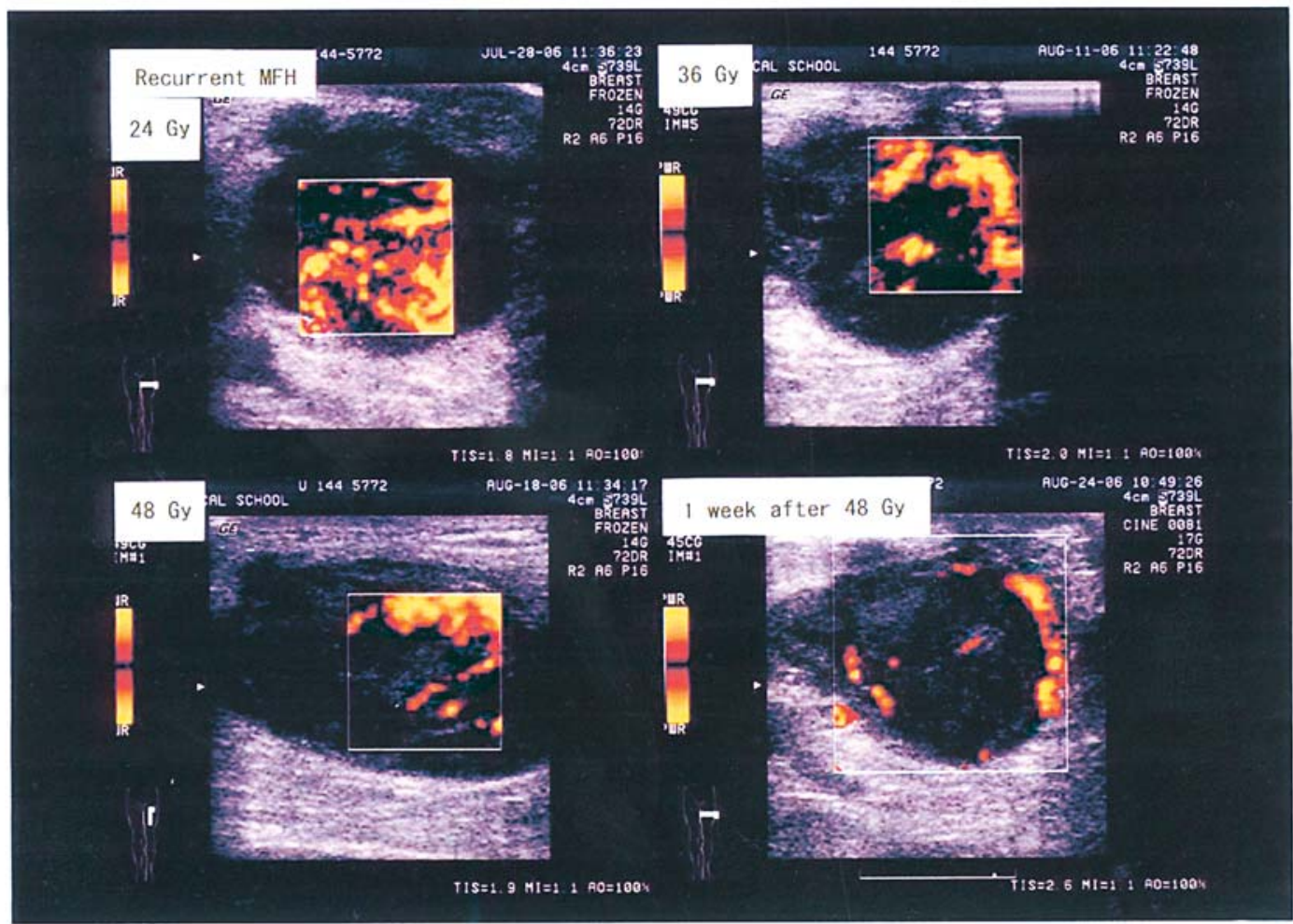

Figure 2. Evidence of the therapeutic effects of KORTUC II for a patient with recurrent and unresectable malignant fibrous histiocytoma (case 2). Tumor blood flow gradually decreased and almost disappeared with continued radiation therapy using presensitization with intratumoral injection of the new agent.

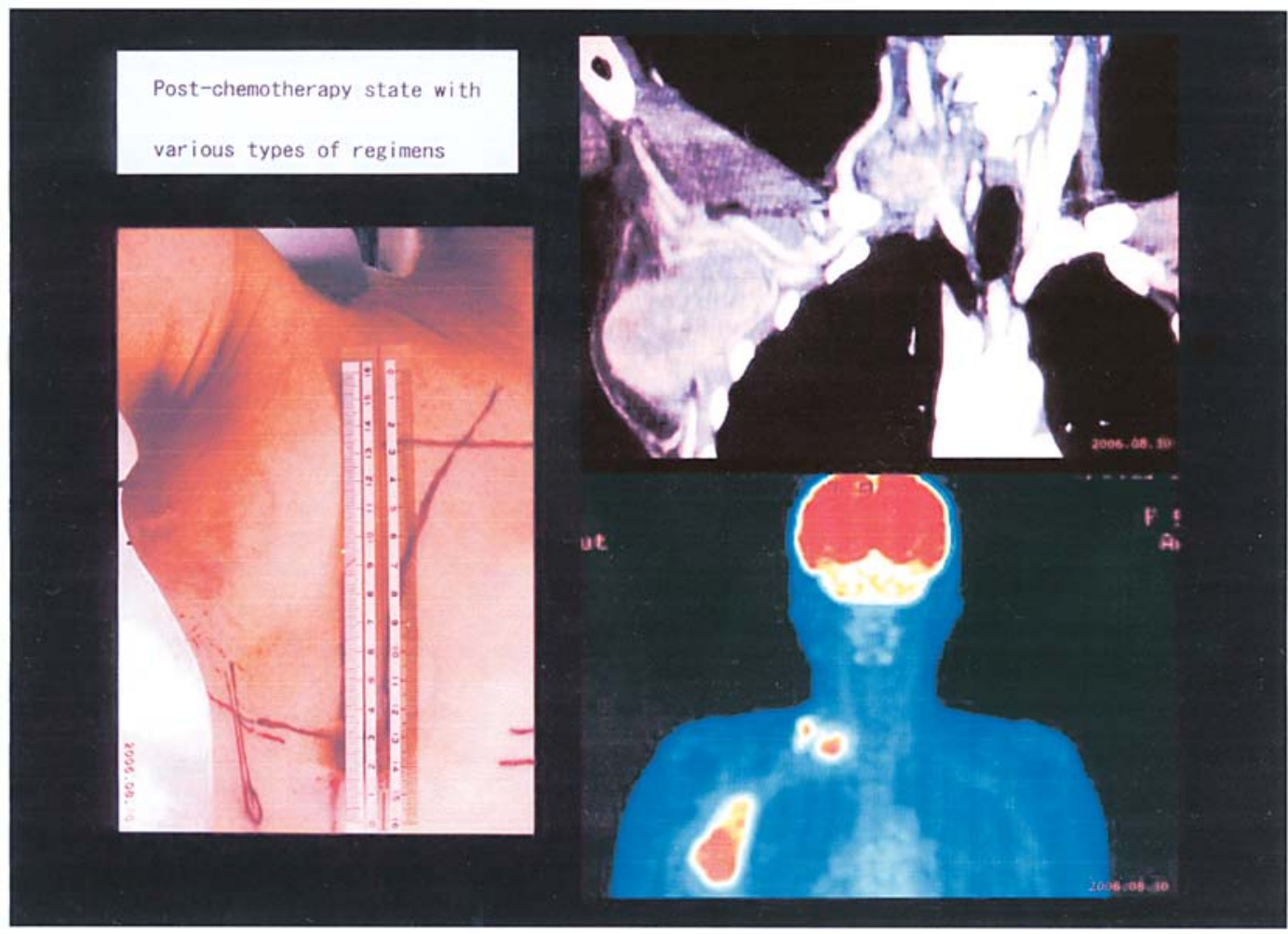

Figure 3. A patient with giant chemotherapy-resistant metastatic lymphadenopathy secondary to breast cancer (case 1).

undergo surgery and therefore undertook non-surgical breastconservation treatment. These patients have so far shown neither local recurrence nor distant metastasis. Of the 3 remaining patients with $\mathrm{CR}$, one had chemotherapy-resistant giant axillary and supraclavicular lymph node metastases of breast cancer, one had recurrent malignant fibrous histiocytoma 


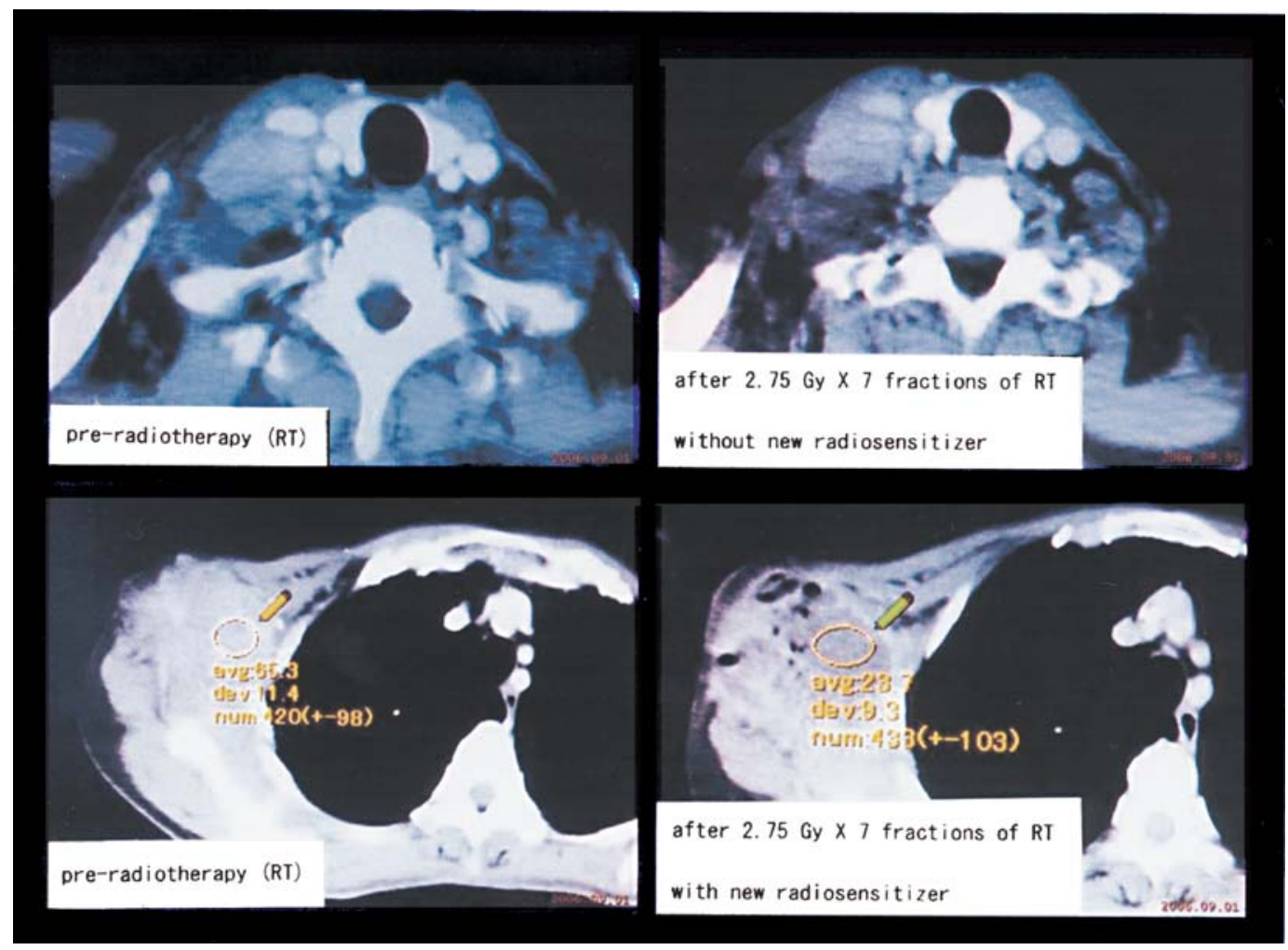

Figure 4. Evidence of the therapeutic effects of KORTUC II for the patient shown in Fig. 3 (case 1). Radiation therapy was performed with tangential fields, including both the right axillary and right supraclavicular metastatic nodes. The supraclavicular nodes were irradiated without KORTUC II treatment, while the axillary nodes were injected with the radiosensitizing agent before radiotherapy. CT images taken 10 days following the start of radiotherapy, after a radiation dose of $19.25 \mathrm{~Gy}$ ( 7 fractions at $2.75 \mathrm{~Gy} /$ fraction), show remarkable degeneration of the presensitized nodes but almost no therapeutic effect in the nodes that received irradiation alone. From the day after this CT imaging, we also administered the sensitizing agent to the right supraclavicular lymph nodes, according to the patient's request.

$(\mathrm{MFH})$, and the other had recurrent fibrous sarcoma. The patient with PR had giant metastatic lymphadenopathy of the neck. The tumor that exhibited NC was a large recurrent malignant schwannoma on the right foot.

Adverse events are described in detail in Table II. Six patients experienced minor adverse events; all were mild local pain at the injection site. For all 11 patients, radiationinduced dermatitis was mild (Grade I, Table I) and equivalent to that observed at our facility after radiation therapy alone.

In patients who responded, the therapeutic effects of KORTUC II have continued, on average, for $>12$ months. Representative cases are shown in Figs. 2-11.

\section{Discussion}

We have reported previously (4) on a highly effective radiosensitization method (KORTUC I) using 3\% hydrogen peroxide solution (Oxydol)-soaked gauze for patients with superficially exposed and unresectable neoplasms. Since many patients have non-superficially exposed neoplasms such as locally advanced breast cancer, recurrent hepatocellular carcinoma, and unresectable pancreatic cancer, the development of a new radiosensitizer for tumor injection is considered to be of utmost importance. We have developed a radiosensitizer that can be safely injected into human tumor tissue under ultrasonographic guidance, and we herein report on the clinical application of this new radiosensitization treatment (KORTUC II).
Currently, most radiation therapy is performed using $\mathrm{X}$-rays or high-energy electron beams from a linear accelerator; however, these forms of radiation are not ideal in terms of their low-linear energy transfer (LET) characteristics. Almost two-thirds of the radiation-induced damage to cancer cells caused by these low-LET beams is brought about by the production of reactive oxygen species (ROS) in irradiated cells (9). Therefore, oxygen is essential for oxidizing the radicals produced by irradiation. In contrast, anti-oxidative enzymes such as peroxidase/catalase scavenge radicals produced by irradiation, resulting in a decreased irradiation effect. Peroxidase/catalase is present in most tumor tissues, as demonstrated by the fact that intrinsic peroxidase must be blocked before immunohistochemical staining of tumor tissue $(10,11)$.

To overcome the disadvantages of these low-LET beams, carbon ion beam radiotherapy has been developed. This form of radiotherapy uses high-LET beams and improves local control, resulting in better survival for patients with unresectable osteosarcoma (12). However, as constructing carbon beam facilities is extremely expensive, there is an urgent need for chemical alternatives that transform radioresistant tumors into radiosensitive ones in response to low LET radiation.

Among the numerous types of human cells, peripheral $\mathrm{T}$ cells are considered to be representative as regards their high level of radiosensitivity $(13,14)$. Because human peripheral $\mathrm{T}$ cells lack peroxidase activity, these cells are easily 


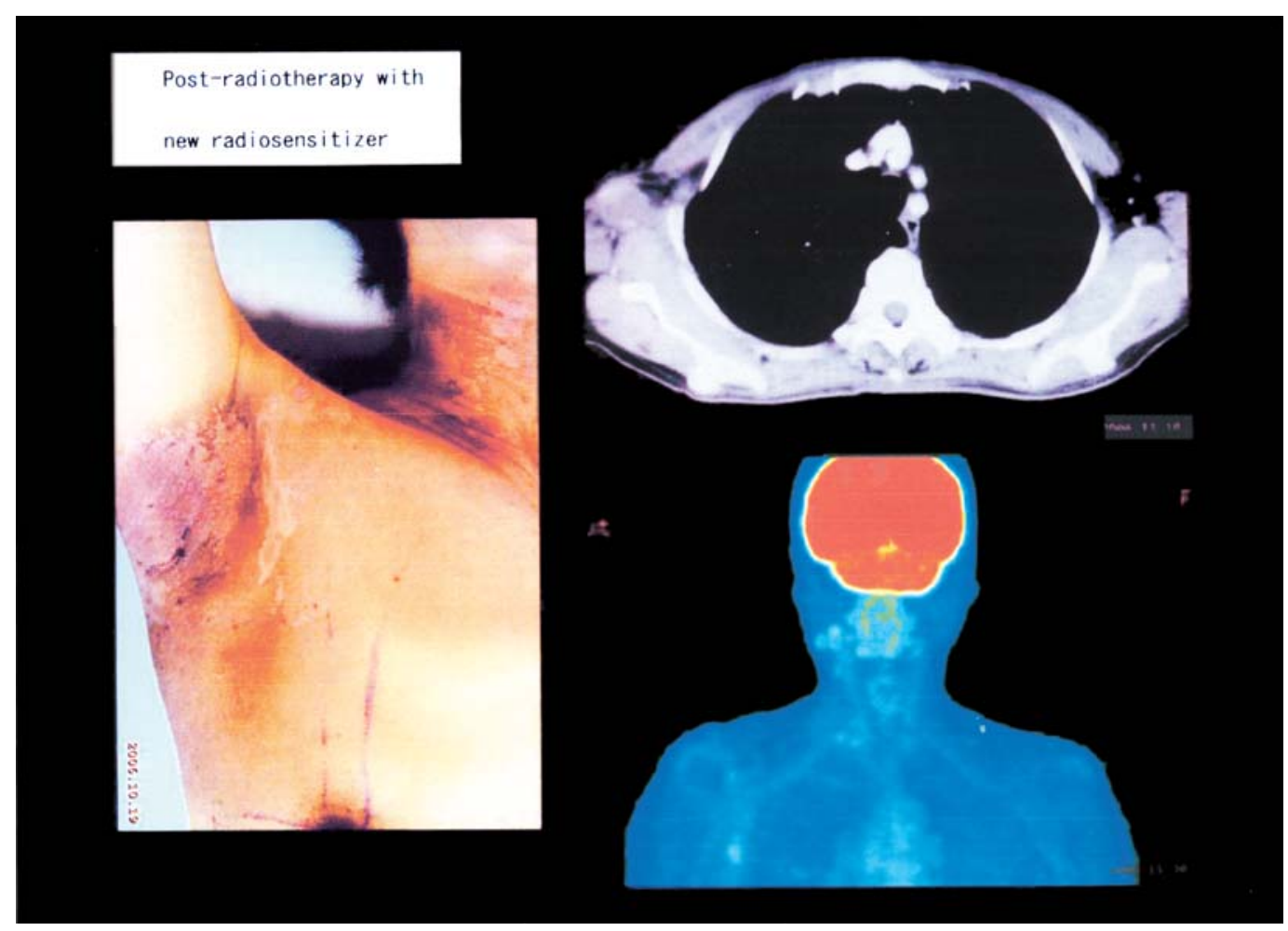

Figure 5. Images of case 1 taken 1 month after the KORTUC II treatment, revealing CR of the lesions.
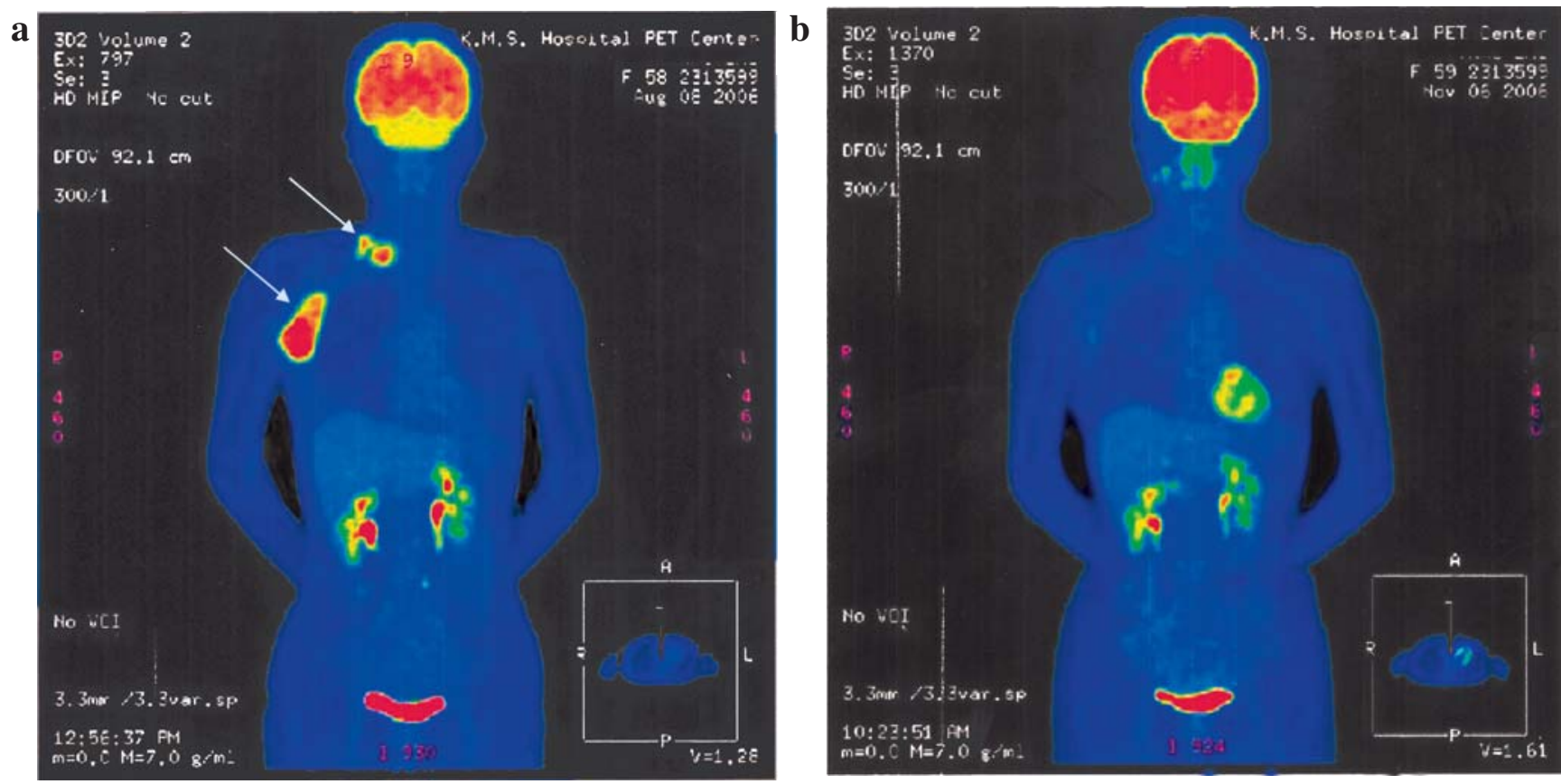

Figure 6. PET-CT images of case 1 before KORTUC II (a, arrows show metastatic lymph nodes) and 1 month after KORTUC II (b, metastatic lesions have completely disappeared).

susceptible to oxidative stress such as that caused by ROS, including hydrogen peroxide $(15,16)$. Therefore, when $\mathrm{T}$ cells are irradiated, hydrogen peroxide produced by reactive oxygen species accumulates in the cytoplasm of lymphocytes and then moves into the lysosomes resulting in lysosomal membrane dysfunction causing apoptosis $(17,18)$. In contrast, osteosarcoma cells are well known to be highly resistant to
low-LET radiation, and we demonstrated by peroxidase staining that these cells contain abundant peroxidase (3). By adding low concentrations of hydrogen peroxide to the medium of the osteosarcoma cell line, these cells are easily converted to a highly radiosensitive state (2).

Although various methods of radiosensitizing treatment for radioresistant neoplasms have been developed (19-23), 


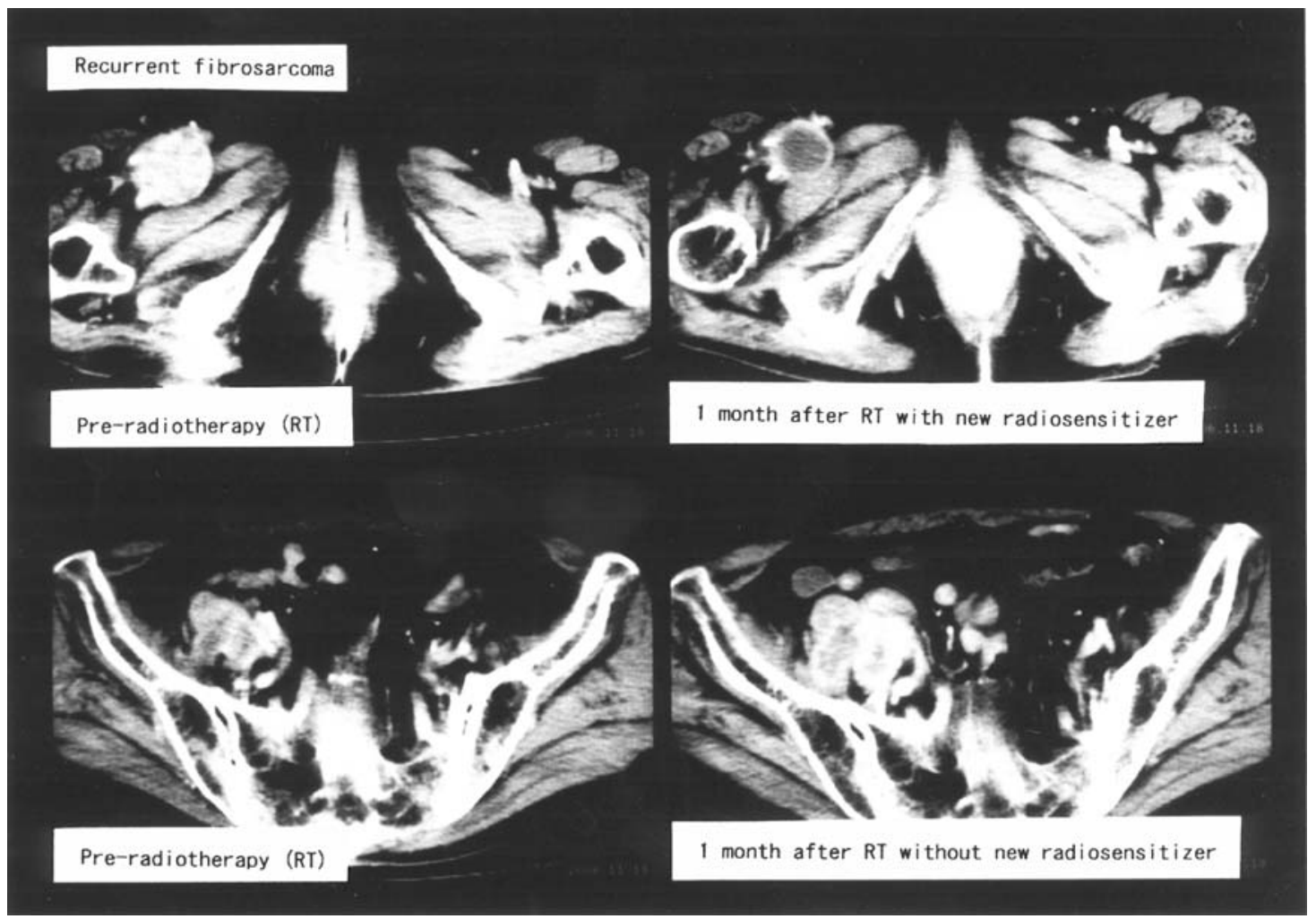

Figure 7. CT images of a patient with recurrent fibrosarcoma treated with KORTUC II (case 4). Radiation therapy was performed to include metastases in both the right inguinal and right iliac lymph nodes; the former was presensitized while the latter was not. CT images taken 1 month after termination of radiotherapy show remarkable therapeutic effects for the presensitized inguinal lymph node in contrast to progression of disease in the iliac lymph node that received irradiation alone.

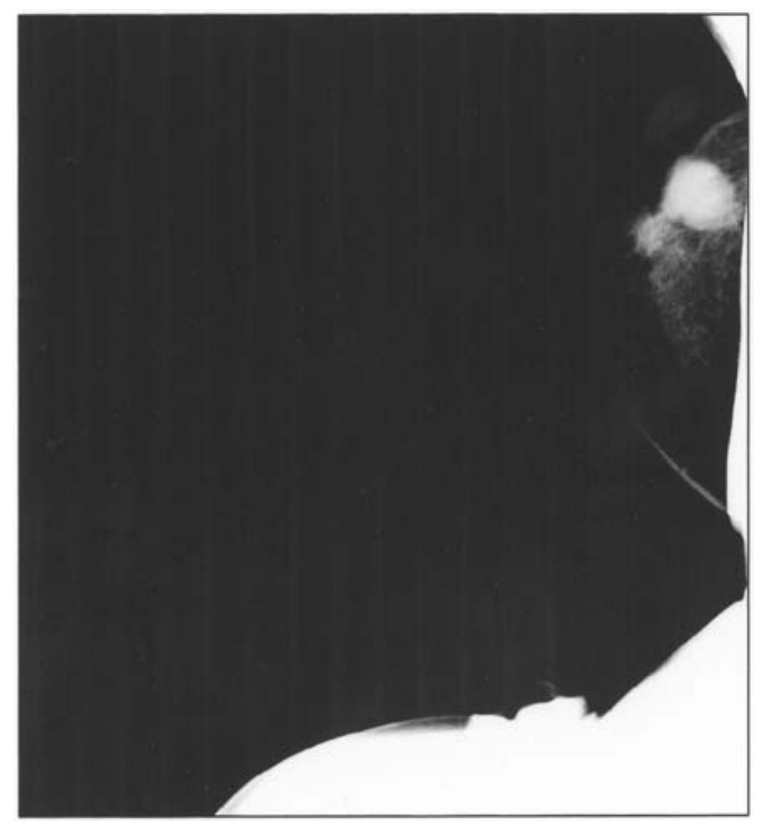

b

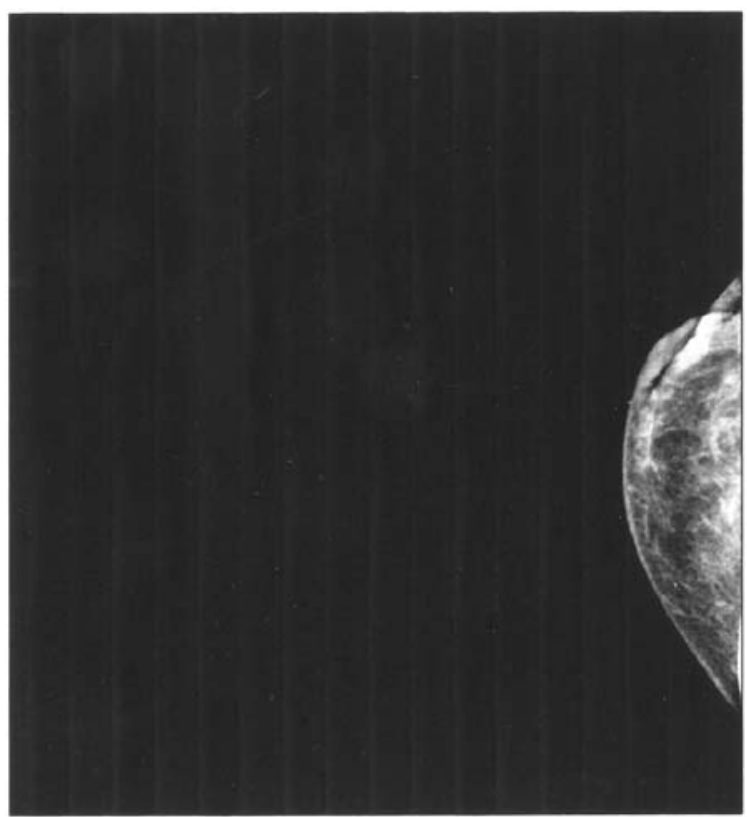

Figure 8. Mammographic images of a breast cancer patient (case 5) before KORTUC II (a) and 3 months after KORTUC II (b, the lesion has completely disappeared).

a clinically applicable method has yet to be established. Many studies have been performed to increase tissue oxygen concentrations to promote the oxidation of radicals produced by low-LET irradiation to cancer cells/tissues, and few therapeutic gains have thus far been observed (24-26). Besides increasing tissue oxygen concentrations, it is considered important to inactivate anti-oxidative enzymes such as peroxidase/catalase. Hydrogen peroxide is the only agent that both inactivates anti-oxidative enzymes and produces oxygen in topical tumor tissue. 
a

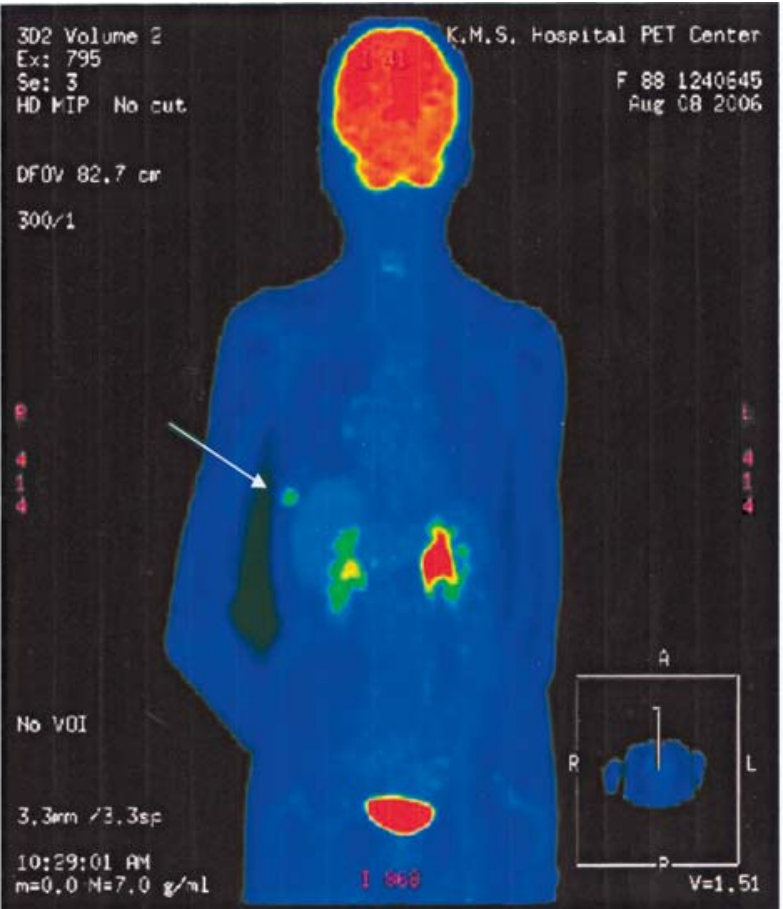

b

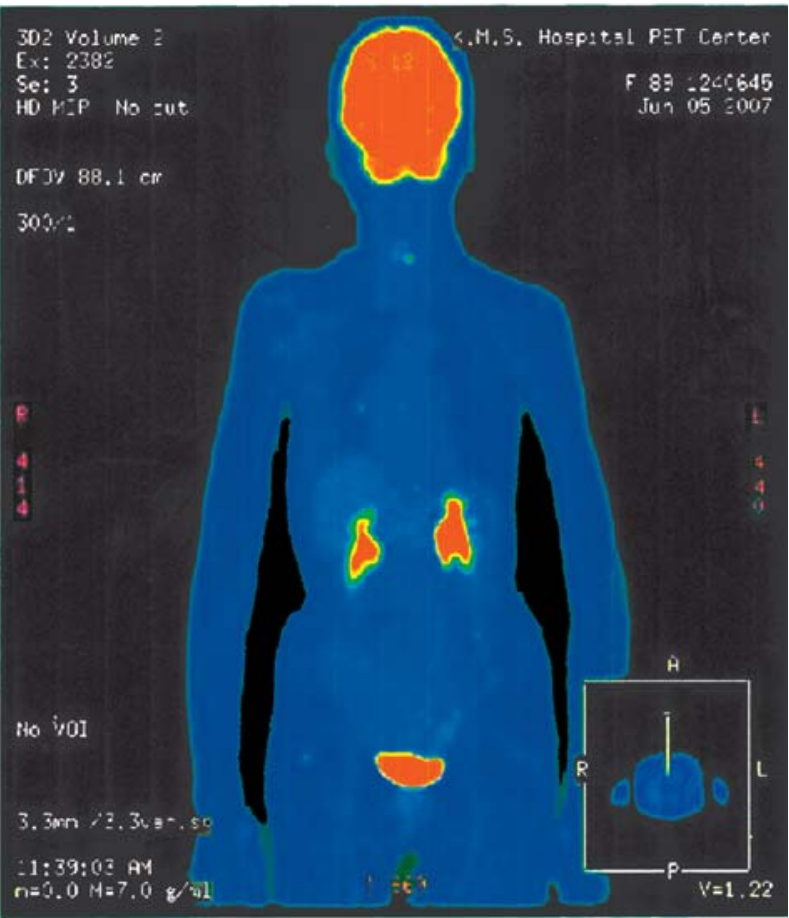

Figure 9. PET-CT images of an elderly patient with breast cancer (case 6) before KORTUC II (a, an arrow shows breast cancer) and 8 months after KORTUC II (b, the lesion has completely disappeared).

a

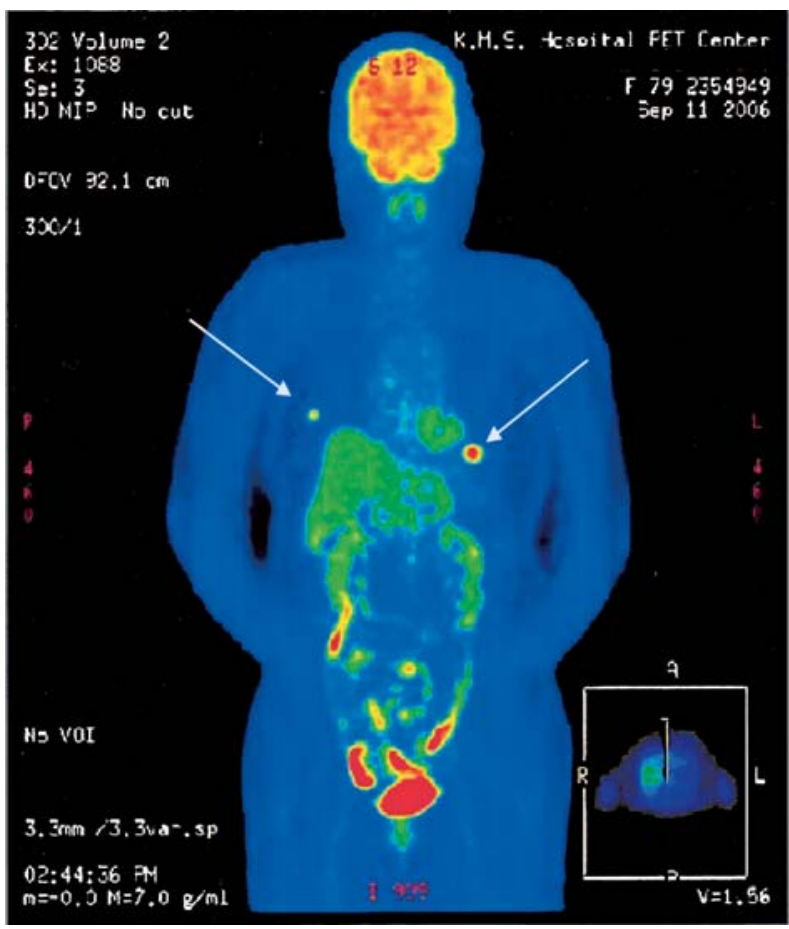

b

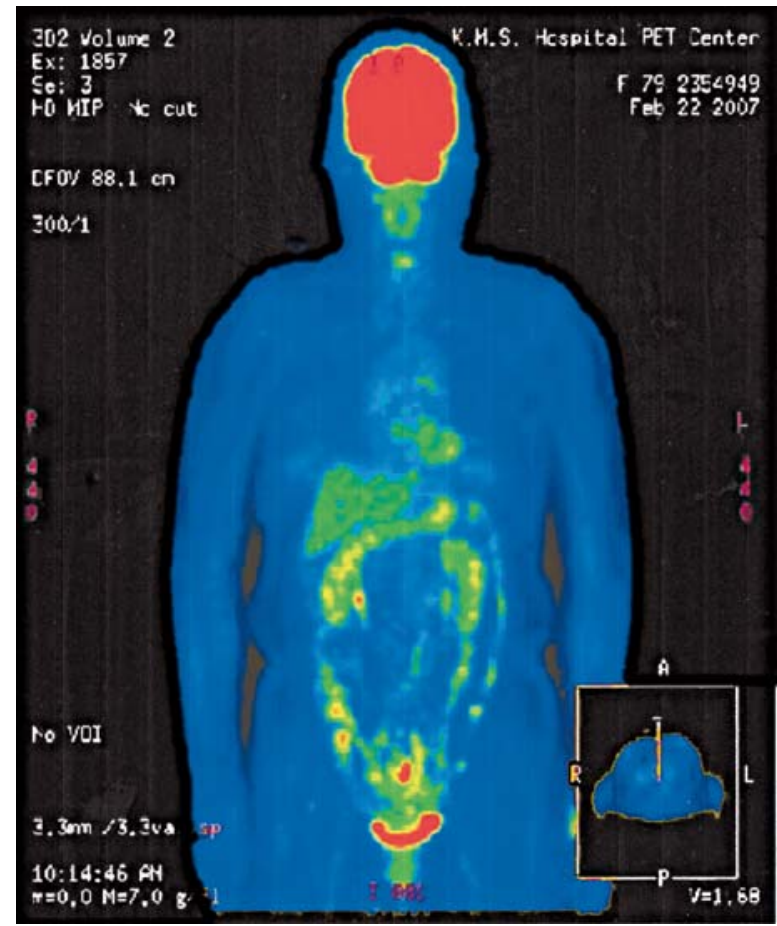

Figure 10. PET-CT images of an elderly patient with bilateral breast cancer (case 7) before KORTUC II (a, arrows show breast cancer) and 3 months after KORTUC II (b, lesions have completely disappeared).

When treating low-LET radioresistant tumors, it is therefore necessary to develop a new method that both inactivates antioxidative enzymes and produces oxygen in tumor tissue in order to augment the effects of X-rays and high-energy electron beams. Tumors that might be amenable to such an approach include malignant melanoma, malignant fibrous histiocytoma (MFH), various types of sarcoma, and most of the relatively large neoplasms (more than several centimeters in diameter) that are frequently seen in daily clinical oncology practice.

Previous studies have demonstrated the ability of hydrogen peroxide to induce apoptosis in numerous types of cells 
a

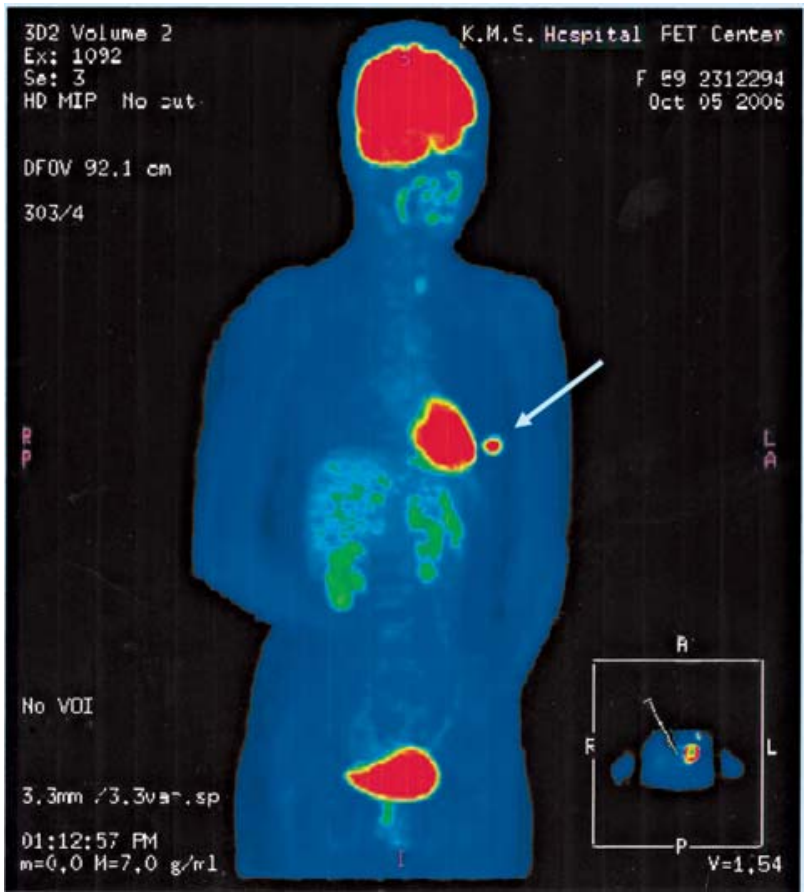

b

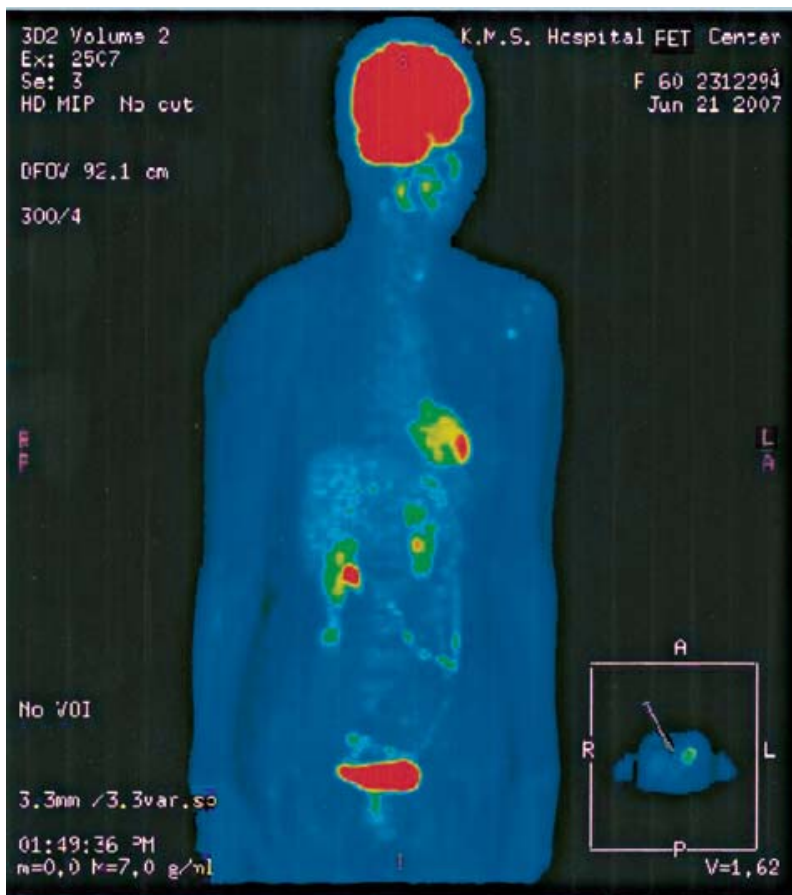

Figure 11. PET-CT images of a breast cancer patient who declined any surgical procedure (case 8); before KORTUC II (a, an arrow shows breast cancer) and 6 months after KORTUC II (b, the lesion has completely disappeared).

(27-30). Hydrogen peroxide is a simple molecule but it has been shown to play an important role in intracellular signal transduction mechanisms. Downstream signaling events that are modulated by hydrogen peroxide include calcium mobilization, protein phosphorylation, and gene expression (31). Excess amounts of exogenous hydrogen peroxide are considered to have rapid and potentially disastrous effects on the ability of individual cells to scavenge ROS. In addition, exogenous hydrogen peroxide can increase intracellular hydrogen peroxide accumulation (32) and activate MAPK (mitogen-activated protein kinase) pathways (33), possibly resulting in mitochondrial dysfunction and amplification of the oxidative death cycle (34).

In the late 1960 s and early 1970 s, several studies investigated the use of hydrogen peroxide in radiotherapy. The majority of reports describe intra-arterial infusions of hydrogen peroxide during radiotherapy. This line of investigation appears to have been discontinued because of difficulties with this method of delivering hydrogen peroxide, as well as lack of improved efficacy (35-37). For example, in the technique of Mallams et al, $250 \mathrm{ml}$ of $0.12 \%$ hydrogen peroxide was perfused intra-arterially in about thirty minutes (38). Regarding intratumoral hydrogen peroxide injection (39), 3-5 $\mathrm{ml}$ of 3\% hydrogen peroxide solution (Oxydol) was administered for meningioma with no significant side effects. Our method, KORTUC II, uses only 3-6 ml of 0.5\% hydrogen peroxide for tumor injection, hence our dose of hydrogen peroxide was much lower than those given in the two methods described above $(38,39)$. Moreover, the combined use of sodium hyaluronate with hydrogen peroxide preserved oxygen concentration in tumor tissue for $>24 \mathrm{~h}$, while intratumoral injection of hydrogen peroxide alone results in rapid lowering of oxygen concentration (unpublished data). Currently, sodium hyaluronate agent is used worldwide for intraarticular (40) and intra-dermal injection (41), for chronic joint disorder and anti-aging treatment of facial skin, respectively. Therefore, the combined use of sodium hyaluronate and hydrogen peroxide in our study, KORTUC II, is considered to be a safe method based on the above-mentioned facts and our experimental results already reported (5).

KORTUC II represents a novel form of treatment using a new radiosensitizer containing hydrogen peroxide and sodium hyaluronate for tumor injection under ultrasonographic guidance. Patients who might benefit include those with locally advanced breast cancer, advanced skin cancer, or metastatic lymph nodes. The treatment was well tolerated, with a minimum of adverse effects such as local pain at the injection site. However, evidence of radiosensitization was demonstrated in only two cases (cases 1 and 4) in terms of comparison of KORTUC II-treated lesions with those treated by radiotherapy alone, and further study is needed to confirm the radiosensitization effect of KORTUC II.

In conclusion, the new radiosensitizer for topical tumor injection contains only hydrogen peroxide and sodium hyaluronate, substances considered not to cause severe adverse effects because they are degraded into water and oxygen in the presence of peroxidase/catalase. The method is targeted at intrinsic peroxidase/catalase present in tumor cells, infiltrating granulocytes, and contaminating red blood cells in the tumor tissue, and the agent is injected into the target tumor tissue under ultrasonographic guidance. Therefore, the method is considered to be a new enzyme-targeting radiosensitization treatment with potential indication for various types of low LET-radioresistant neoplasms. Based on our experimental data, it can be concluded that hydrogen peroxide is a radiation sensitizer. Moreover, the present study showed that the present 
formulation can be delivered safely under the conditions used in this study.

\section{Acknowledgements}

The authors would like to thank Mr. Norikazu Yokota, Mr. Toshikazu Sasaki, Mr. Akira Tsuzuki, Ms. Shiho Tokuhiro, and Ms. Maiko Shinagawa for their assistance with this work. This study was presented at the 100th Anniversary of Tohoku University, the 5th Japan-US Cancer Therapy Symposium, and 5th S. Takahashi Memorial International Joint Symposium Improving Therapeutic Ratio with Radiation and Molecular Targeted Treatment - held in Sendai, Japan, September 2007.

\section{References}

1. Ogawa Y, Takahashi T, Kobayashi T, et al: Mechanism of apoptotic resistance of human osteosarcoma cell line, HS-Os-1, against irradiation. Int J Mol Med 12: 453-458, 2003.

2. Ogawa Y, Takahashi T, Kobayashi T, et al: Apoptoticresistance of the human osteosarcoma cell line HS-Os-1 to irradiation is converted to apoptotic-susceptibility by hydrogen peroxide: a potent role of hydrogen peroxide as a new radiosensitizer. Int J Mol Med 12: 845-850, 2003.

3. Ogawa Y, Takahashi T, Kobayashi T, et al: Immunocytochemical characteristics of human osteosarcoma cell line HSOs-1: Possible implication in apoptotic resistance against irradiation. Int J Mol Med 14: 397-403, 2004.

4. Ogawa $\mathrm{Y}$, Ue $\mathrm{H}$, Tsuzuki $\mathrm{K}$, et al: New radiosensitization treatment (KORTUC I) using hydrogen peroxide solutionsoaked gauze bolus for unresectable and superficially exposed neoplasms. Oncol Rep 19: 1389-1394, 2008.

5. Ogawa Y, Kubota K, Ue H, et al: Development and clinical application of a new radiosensitizer containing hydrogen peroxide and hyaluronic acid sodium for topical tumor injection - a new enzyme-targeting radiosensitization treatment, KORTUC II (Kochi Oxydol-Radiation Therapy for Unresectable Carcinomas, Type II). Strahlenther Onkol 183 (Sondernr.2): 100-101, 2007.

6. Ogawa Y, Nishioka A, Inomata T, et al: Conservation treatment intensified with an anti-estrogen agent and CAF chemotherapy for stage I and II breast cancer. Oncol Rep 7: 479-484, 2000.

7. Ogawa Y, Nishioka A, Inomata T, et al: Conservation treatment intensified with tamoxifen and CAF chemotherapy without axillary dissection for early breast cancer patients with clinicallynegative axillary nodes. Oncol Rep 6: 801-805, 1999.

8. Therasse P, Arbuck SG, Eisenhauer EA, et al: New guidelines to evaluate the response to treatment in solid tumors. J Natl Cancer Inst 92: 205-216, 2000.

9. Hall EJ (ed): The oxygen effect and reoxygenation. In: Radiobiology for the Radiologist. 5th edition. J.B. Lippincott Co., Philadelphia, PA, pp91-111, 2000.

10. Ogawa Y, Nishioka A, Hamada N, et al: Immunohistochemical study of c-fos-positive lymphocytes infiltrated into human squamous cell carcinomas of the head and neck radiation therapy and its clinical significance. Clin Cancer Res 3: 2301-2307, 1997.

11. Ogawa Y, Nishioka A, Hamada N, et al: Expression of Fas (CD95/APO-1) antigen induced by radiation therapy for diffuse B-cell lymphoma: immunohistochemical study. Clin Cancer Res 3: 2211-2216, 1997.

12. Kamada T, Tsujii H, Tsuji H, et al: Efficacy and safety of carbon ion radiotherapy in bone and soft tissue sarcomas. J Clin Oncol 20: 4466-4471, 2002.

13. Ogawa Y, Nishioka A, Inomata $\mathrm{T}$, et al: Radiation kills human peripheral $\mathrm{T}$ cells by a Fas-independent mechanism. Int $\mathrm{J}$ Mol Med 2: 403-408, 1998.

14. Ogawa Y, Nishioka A, Kobayashi T, et al: Mitochondrial cytochrome $\mathrm{c}$ release in radiation-induced apoptosis of human peripheral T cells. Int J Mol Med 1: 263-268, 1998.

15. Ogawa Y, Nishioka A, Kobayashi T, et al: Radiation-induced apoptosis of human peripheral T cells: analyses with c DNA expression arrays and mitochondrial membrane potential assay. Int J Mol Med 7: 603-607, 2001.

16. Ogawa Y, Kobayashi T, Nishioka A, et al: Radiation-induced oxidative DNA damage, 8-oxoguanine, in human peripheral T cells. Int J Mol Med 11: 27-32, 2003.
17. Ogawa Y, Kobayashi T, Nishioka A, et al: Radiation-induced reactive oxygen species (ROS) formation in human peripheral $\mathrm{T}$ cells. Int J Mol Med 11: 149-152, 2003

18. Ogawa Y, Kobayashi T, Nishioka A, et al: Reactive oxygen species-producing site in radiation-induced apoptosis of human peripheral T cells: involvement of lysosomal membrane destabilization. Int J Mol Med 13: 69-73, 2004.

19. Lawrence TS, Blackstock AW and McGinn C: The mechanism of action of radiosensitization of conventional chemotherapeutic agents. Semin Radiat Oncol 13: 13-21, 2003.

20. Bohm L, Roos, WP and Serafin AM: Inhibition of DNA repair by pentoxifylline and related methylxanthine derivatives. Toxicology 193: 153-160, 2003.

21. Milas L: Cyclooxygenase-2 (COX-2) enzyme inhibitors as potential enhancers of tumor radioresponse. Semin Radiat Oncol 11: 290-299, 2001

22. Choy $\mathrm{H}$ and Milas L: Enhancing radiotherapy with cyclooxygenase- 2 enzyme inhibitors: a rational advance? J Natl Cancer Inst 95: 1440-1452, 2003.

23. Overgaad J: Clinical evaluation of nitroimidazoles as modifiers of hypoxia in solid tumors. Oncol Res 6: 509-518, 1994.

24. Gerlach NL, Barkhuysen R, Kaanders JH, et al: The effect of hyperbaric oxygen therapy on quality of life in oral and oropharyngeal cancer patients treated with radiotherapy. Int J Oral Maxiilofac Surg 37: 255-259, 2008.

25. Overgaad J: Hypoxic radiosensitization: adored and ignored. J Clin Oncol 25: 4066-4074, 2007.

26. Williamson RA: An experimental study of the use of hyperbaric oxygen to reduce the side effects of radiation treatment for malignant disease. Int J Oral Maxillofac Surg 36: 533-540, 2007.

27. Wagner BA, Britigan BE, Reszka KJ, et al: Hydrogen peroxideinduced apoptosis of HL-60 human leukemia cells is mediated by the oxidants hypochlorous acid and chloramines. Arch Biochem Biophys 401: 223-234, 2002.

28. Li JM, Zhou H, Cai Q and Xiao GX: Role of mitochondrial dysfunction in hydrogen peroxide-induced apoptosis of intestinal epithelial cells. World J Gastroenterol 9: 562-567, 2003.

29. Barbouti A, Doulias PT, Nousis L, et al: DNA damage and apoptosis in hydrogen peroxide-exposed Jurkat cells: bolus addition versus continuous generation of $\mathrm{H}_{2} \mathrm{O}_{2}$. Free Radic Biol Med 33: 691-702, 2002.

30. Frossi B, Tell G, Spessotto $\mathrm{P}$, et al: $\mathrm{H}_{2} \mathrm{O}_{2}$ induces translocation of APE/Ref-1 to mitochondria in the Raji B-cell line. J Cell Physiol 193: 180-186, 2002.

31. Neil S, Desikan R and Hancock J: Hydrogen peroxide signaling. Curr Opin Plant Biol 5: 389-395, 2002.

32. Maxwell DP, Nickels R and McIntosh L: Evidence of mitochondrial involvement in the transduction of signals required for the induction of genes associated with pathogen attack and senescence. Plant J 29: 269-279, 2002.

33. Kovtun Y, Chiu W-L, Tena G and Sheen J: Functional analysis of oxidative stress-activated mitogen-activated protein kinase cascade in plants. Proc Natl Acad Sci USA 97: 2940-2945, 2000.

34. Van Camp W, van Montage and Inze D: $\mathrm{H}_{2} \mathrm{O}_{2}$ and NO: redox signals in disease resistance. Trends Plant Sci 3: 330-334, 1998.

35. Chasin WD, Gross CC, Wang CC and Miller D: Hydrogen peroxide and irradiation of tumors. Arch Otolaryngol 85: 151-155, 1967.

36. Bianchini G, Salgarello G, Mennini T and Lorini G: Intraarterial infusion of hydrogen peroxide in radiotherapy of malignant tumors. Radiol Med (Torino) 55: 207-225, 1969.

37. Whittle RJ: Technique and results of radiotherapy aided by arterial infusion of hydrogen peroxide. Nunt Radiol 34: 191-205, 1968.

38. Mallams JT, Balla GA and Finney JW: Regional intra-arterial hydrogen peroxide infusion and irradiation in the treatment of head and neck malignancies: a progress report. Trans Am Acad Ophthalmol Otolaryngol 67: 546-553, 1963.

39. Lichtenbaum R, De Souza AA and Jafar JJ: Intratumoral hydrogen peroxide injection during meningioma resection. Neurosurgery 59 (ONS Suppl. 4): 470-473, 2006.

40. Karatosun V, Unver B, Ozden A, et al: Intra-articular hyaluronic acid compared to exercise therapy in osteoarthritis of the ankle. A prospective randomized trial with long-term follow-up. Clin Exp Rheumatol 26: 288-294, 2008.

41. Brandt FS, Cazzaniga A: Hyaluronic acid gel fillers in the management of facial aging. Clin Interv Aging 3: 153-159, 2008. 